\title{
Influence of energetic particle precipitation on Antarctic stratospheric chlorine and ozone over the 20th century
}

\author{
Ville Maliniemi ${ }^{1}$, Pavle Arsenovic ${ }^{2,1}$, Annika Seppälä ${ }^{3}$, and Hilde Nesse Tyssøy ${ }^{1}$ \\ ${ }^{1}$ Birkeland Centre for Space Science, Department of Physics and Technology, University of Bergen, Norway \\ ${ }^{2}$ Risk Management Solutions, London, UK \\ ${ }^{3}$ Department of Physics, University of Otago, Dunedin, New Zealand
}

Correspondence: Ville Maliniemi (ville.maliniemi@uib.no)

\begin{abstract}
Chlorofluorocarbon (CFC) emissions in the latter part of the 20th century reduced stratospheric ozone abundance substantially, especially in the Antarctic region. Simultaneously, polar stratospheric ozone is also destroyed catalytically by nitrogen oxides $\left(\mathrm{NO}_{x}=\mathrm{NO}+\mathrm{NO}_{2}\right)$ descending from the mesosphere and the lower thermosphere during winter. These are produced by energetic particle precipitation (EPP) linked to solar activity and space weather. $\mathrm{NO}_{x}$ and active chlorine $\left(\mathrm{ClO}_{x}=\mathrm{Cl}+\mathrm{ClO}\right)$ also react mutually and transform both reactive agents into reservoir gas chlorine nitrate, which buffers ozone destruction by both $\mathrm{NO}_{x}$ and $\mathrm{ClO}_{x}$. We study the interaction between EPP produced $\mathrm{NO}_{x}, \mathrm{ClO}$ and ozone over the 20th century by using free running climate simulations of the chemistry-climate model SOCOL3-MPIOM. Substantial increase of $\mathrm{NO}_{x}$ descending to polar stratosphere is found during winter, which causes ozone depletion in the upper and mid-stratosphere. However, in the Antarctic mid-stratosphere the EPP induced ozone depletion becomes less efficient after 1960s, especially during springtime. Simultaneously, significant decrease in stratospheric $\mathrm{ClO}$ and increase in chlorine nitrate between 10-30 $\mathrm{hPa}$ can be ascribed to EPP forcing. Hence, interaction between $\mathrm{NO}_{x}$ and $\mathrm{ClO}$ likely suppressed the ozone depletion due to both $\mathrm{EPP}-\mathrm{NO}_{x}$ and $\mathrm{ClO}$ at these altitudes. Furthermore, at the end of the century significant $\mathrm{ClO}$ increase and ozone decrease is obtained at $100 \mathrm{hPa}$ altitude during winter and spring. This lower stratosphere response is likely due to activation of chlorine from reservoir gases on polar stratospheric clouds. Our results show that EPP has been a significant modulator of reactive chlorine in the Antarctic stratosphere during the CFC era. With the implementation of the Montreal Protocol, stratospheric chlorine is estimated to return to pre-CFC era levels after 2050. Thus, we expect increased efficiency of chemical ozone destruction by EPP-NO ${ }_{x}$ in the Antarctic upper and mid-stratosphere over coming decades. The future lower stratosphere ozone response by EPP is more uncertain.
\end{abstract}

\section{Introduction}

Chlorofluorocarbon (CFC) emissions caused stratospheric ozone to decrease substantially during the latter half of the 20th century (WMO, 2018). This was especially dramatic in the Antarctic where the ozone hole formed in the lower stratosphere (Anderson et al., 1991). 
Atmospheric chlorine released from the CFC emissions can destroy ozone via catalytic reactions like

$\mathrm{ClO}+\mathrm{O} \rightarrow \mathrm{Cl}+\mathrm{O}_{2}$.

$$
\mathrm{Cl}+\mathrm{O}_{3} \rightarrow \mathrm{ClO}+\mathrm{O}_{2} .
$$

This reaction chain has a peak effectiveness in the upper stratosphere between 40 and 50km altitudes (Lary, 1997). For the most part of the year, chlorine in the lower stratosphere is stored in a reservoir gases like chlorine nitrate $\left(\mathrm{ClONO}_{2}\right)$ and hydrogen chloride ( $\mathrm{HCl}$ ) (Molina et al., 1987). During winter, the Antarctic lower stratosphere has cold enough temperatures to form polar stratospheric clouds (PSC) (Pitts et al., 2018). Chemical reactions on PSCs break chlorine reservoir gases to reactive chlorine $\mathrm{ClO}$ (Molina et al., 1987), leading to catalytic ozone depletion during spring via the chain of reactions:

$\mathrm{ClO}+\mathrm{ClO}+\mathrm{M} \rightarrow \mathrm{Cl}_{2} \mathrm{O}_{2}$

$\mathrm{Cl}_{2} \mathrm{O}_{2}+\mathrm{h} \nu \rightarrow \mathrm{Cl}+\mathrm{ClOO} \rightarrow 2 \mathrm{Cl}+\mathrm{O}_{2}$

$2 \times\left(\mathrm{Cl}+\mathrm{O}_{3} \rightarrow \mathrm{ClO}+\mathrm{O}_{2}\right)$

This reaction chain has a peak effectiveness at 15-20km altitude (Lary, 1997), and is important for the ozone hole formation. One can see the monthly Antarctic ozone climatology and the trend in the latter half of the 20th century in Figure 1.

Polar ozone can also be destroyed catalytically by reactive nitrogen oxides $\left(\mathrm{NO}_{x}=\mathrm{NO}+\mathrm{NO}_{2}\right)$ via reactions:

$\mathrm{NO}+\mathrm{O}_{3} \rightarrow \mathrm{NO}_{2}+\mathrm{O}_{2}$

This reaction chain peaks at $45 \mathrm{~km}$ altitude (Lary, 1997). One of the main sources of polar $\mathrm{NO}_{x}$ is energetic electron precipitation (EEP) from the magnetosphere, which ionizes the polar thermosphere and the upper mesosphere (Mironova et al., 2015; Nesse Tyssøy et al., 2019). In addition, sporadic solar proton events (SPE) can produce $\mathrm{NO}_{x}$ in the mesosphere/upper stratosphere (Jackman et al., 2009). During winter, polar regions remain in darkness which prolongs the chemical lifetime of $\mathrm{NO}_{x}$ (Solomon et al., 1982; Funke et al., 2014). Furthermore, downward vertical residual circulation in the wintertime transports po$\operatorname{lar} \mathrm{NO}_{x}$ to stratospheric altitudes (Seppälä et al., 2007; Maliniemi et al., 2020). It has been shown that this indirect stratospheric $\mathrm{NO}_{x}$ can deplete ozone by 10-15 percent in the Antarctic upper stratosphere during winter (Semeniuk et al., 2011; Damiani 

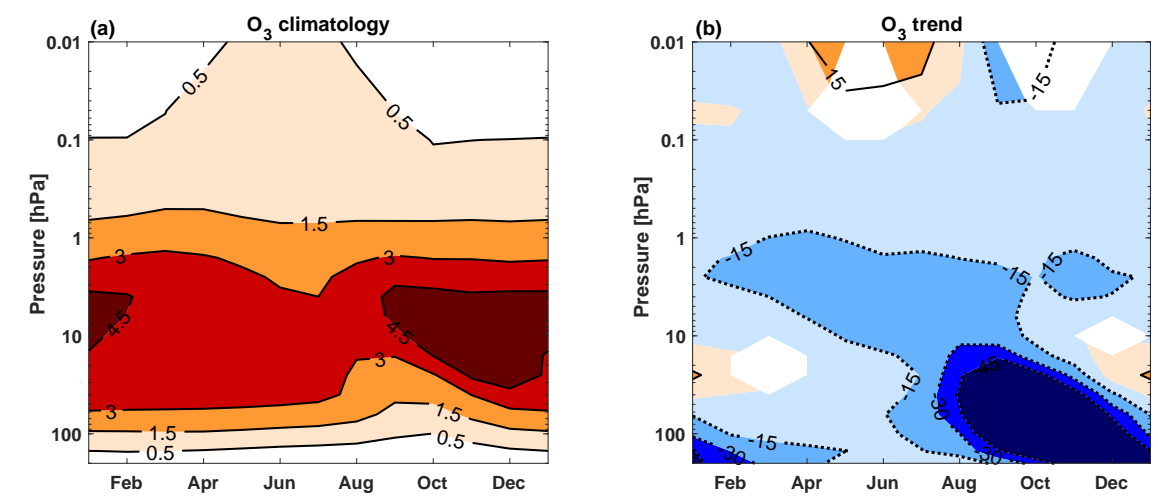

Figure 1. a) Zonal mean ozone climatology in the Antarctic $\left(70^{\circ} \mathrm{S}-90^{\circ} \mathrm{S}, 0.01-200 \mathrm{hPa}\right)$ during $1958-2008$. Contour levels are $0.5,1.5,3$ and 4.5 parts-per-million (ppm). b) Zonal mean ozone trend in the Antarctic ( $\left.70^{\circ} \mathrm{S}-90^{\circ} \mathrm{S}, 0.01-200 \mathrm{hPa}\right)$ during $1958-2008$. Positive contour level (solid line) is 15 percent (\%), and negative contour levels (dotted lines) are -15, -30 and -45 percent. Colour shading indicates areas significant at the $95 \%$ level calculated with a Mann-Kendall test and a false detection rate. Figures were made using the REF simulation (see details in Data and Methods).

et al., 2016; Arsenovic et al., 2019). Galactic cosmic rays (GCR) also impact atmospheric $\mathrm{NO}_{x}$ and ozone. Their ionization peaks around 10-15 km affecting the upper troposphere/lower stratosphere region directly (Calisto et al., 2011; Jackman et al., 2016).

Reactive $\mathrm{NO}_{x}$ gasses also interact with stratospheric $\mathrm{ClO}$ via reactions

$\mathrm{ClO}+\mathrm{NO}_{2} \rightarrow \mathrm{ClONO}_{2}$

$\mathrm{ClO}+\mathrm{NO} \rightarrow \mathrm{Cl}+\mathrm{NO}_{2}$

Reaction R8 stores both reactive nitrogen and chlorine into reservoir agents (Lary, 1997), and thus buffers the ozone destruction associated with both $\mathrm{NO}_{x}$ and $\mathrm{ClO}$. Reaction $\mathrm{R} 9$ couples catalytic ozone destruction cycles of chlorine and $\mathrm{NO}_{x}(\mathrm{Brasseur}$ and Solomon, 2005). A recent study showed that satellite observations of Antarctic $\mathrm{ClO}$ correlated negatively with the geomagnetic activity during springtime (Gordon et al., 2021). This implies that ozone depletion by polar $\mathrm{NO}_{x}$ is modulated by chlorine loading, especially during the CFC era. Similarly, stratospheric indirect $\mathrm{NO}_{x}$ will modulate the ozone depletion by $\mathrm{ClO}$. In this paper we investigate how the interaction between $\mathrm{NO}_{x}, \mathrm{ClO}$ and ozone and the emergence of the CFC era modulate the particle precipitation impact on ozone by using a free running chemistry-climate simulation with implemented particle precipitation forcing over the whole 20th century. 


\section{Data and Methods}

The chemistry-climate model SOCOL3-MPIOM (Stenke et al., 2013; Muthers et al., 2014) consists of three interactively coupled components. The atmospheric component is the general atmospheric circulation model ECHAM5.4 (Roeckner, 2003 ), here used in configuration with T31 spectral horizontal truncation (approximately $3.75^{\circ} \times 3.75^{\circ}$ ) and 30 vertical levels from the surface to $0.01 \mathrm{hPa}(\sim 80 \mathrm{~km})$. ECHAM5.4 is used in free-running mode with prescribed quasi-biannual oscillation (QBO) in the zonal wind, as the model cannot generate the QBO with the applied vertical resolution. The chemistry module MEZON (Egorova et al., 2003) computes the tendencies of 41 gas species, including 200 gas-phase, 16 heterogeneous and 35 photolytic reactions. The oceanic component is MPIOM (Marsland et al., 2003), used in the nominal horizontal resolution of $3^{\circ}$ with 40 vertical layers from the ocean surface to the bottom.

The solar radiation input is based on the study by Shapiro et al. (2011). The precipitating energetic particles are prescribed following the Coupled Model Intercomparison Project Phase 6 (CMIP6) recommendations (Matthes et al., 2017). Mediumenergy electrons $(>30 \mathrm{keV})$ are implemented as daily ionisation rates, while auroral electrons $(<30 \mathrm{keV})$ are represented as NO influx through the model top (Funke et al., 2016). SPEs and GCR are also implemented as daily ionisation rates. The tropospheric aerosols originate from NCAR Community Atmospheric Model (CAM3.5) simulations with a bulk aerosol model forced with the Community Climate System Model 3 sea surface temperatures. The concentrations of greenhouse gases, ozone depleting substances and ozone precursors $\left(\mathrm{CO}\right.$ and $\mathrm{NO}_{x}$ ) follow historic values (Meinshausen et al., 2011).

In this study, the experiment simulation (EXP) contains all energetic particle precipitation sources (EEP+SPE+CGR) along with all other forcings, while the reference simulation (REF) contains all forcings apart from the particle precipitation sources. Total simulation length is 109 years (1900-2008). Timeseries of geomagnetic activity (EEP ionization model is based on the Ap index (Matthes et al., 2017)), SPEs, and GCR can be seen in Figure 2. An eleven-member ensemble was generated by varying initial $\mathrm{CO}_{2}$ concentrations with $0.1 \%$ among the different members of EXP and REF.

For the atmospheric parameters we compute zonal averages and obtain their monthly latitude-height profiles and analyse the EPP response (EXP-REF). We concentrate on volume mixing ratios of $\mathrm{NO}_{x}, \mathrm{ClO}, \mathrm{ClONO}_{2}, \mathrm{HCl}_{\text {and }}$ ozone. Significance in each lat-height bin is calculated with a monte carlo simulation. We combine ensembles from both EXP and REF (22 total) and randomly take two 11-ensemble data collections 10,000 times. These two randomly picked data matrices are subtracted similarly as the original data in each lat-height grid. Original value (EXP-REF) is compared to the distribution of these 10,000 repetitions to obtain the fraction of more extreme differences (both tails of the distribution). This fraction then represents the p-value in each lat-height bin with the null hypothesis that there is no difference between EXP and REF.

Results presented in a latitude-height grid are usually spatially correlated, and represent a multiple hypothesis testing situation (Wilks, 2016). Thus, simply presenting significance in each bin based on individual hypothesis testing will lead to an overestimation of the true number of rejected null-hypotheses. The average number of false positives is $n^{*} p$, where $n$ is the number of hypothesis tests and $\mathrm{p}$ is the used p-value. This is due to the definition of the p-value, and also the dependency of the neighbouring grid points, i.e., the spatial autocorrelation (Wilks, 2016). To overcome this issue, the false discovery rate is calculated for each case. It reduces the probability of false positives in line with the applied new p-value limit. After the 

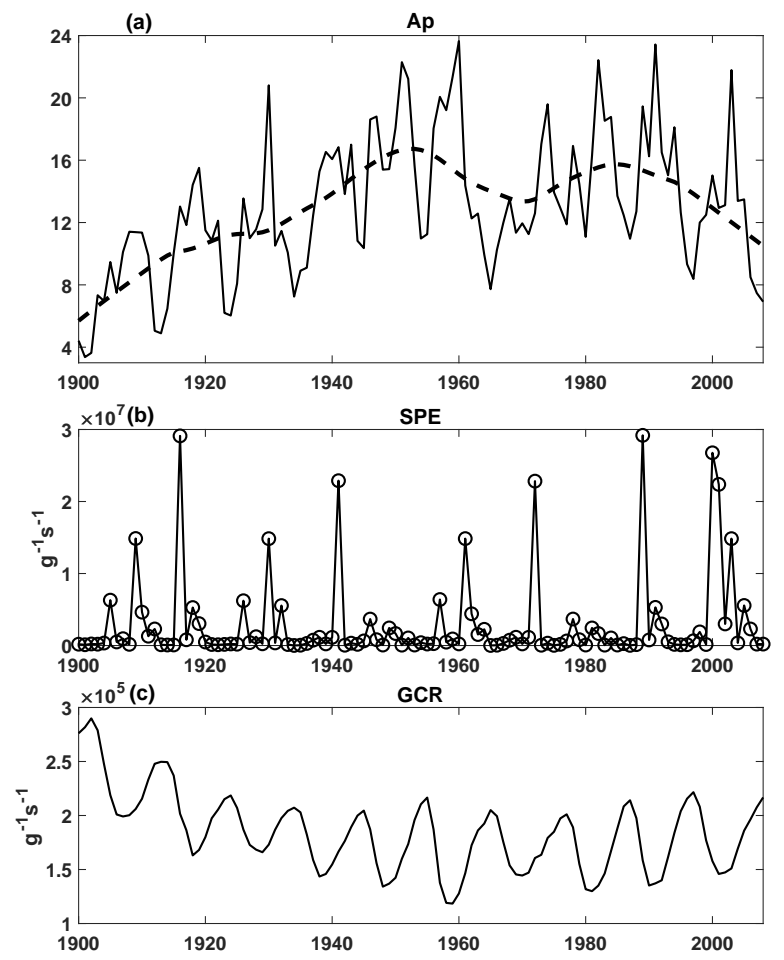

Figure 2. a) Annual time series of geomagnetic activity index Ap (solid line) and 31-year smooth trend (dotted line). b) Annual time series of SPEs (ion pair production rate at $1 \mathrm{hPa}, 70^{\circ} \mathrm{S}-90^{\circ} \mathrm{S}$ ). c) Annual time series of GCR (ion pair production rate at $100 \mathrm{hPa}, 70^{\circ} \mathrm{S}-90^{\circ} \mathrm{S}$ ).

procedure, the p-value can be interpreted as being the probability to obtain a false rejection of a null-hypothesis. Details of the method can be found in Wilks (2016). We have used the p-value limit of 0.05, which then represents 95\% probability of not having any false positives.

Figure 1 shows the relative change in ozone over the Antarctic from 1958 to 2008 in the REF simulation calculated by subtracting a 5-year mean centered on 1960 from a 5-year mean centered on 2006. Significance is calculated using a MannKendall test (Mann, 1945) and a false discovery rate. The smooth long-term variations shown in Figure 2 and the following Figures 7-10 are calculated using the LOWESS-method (LOcally WEighted Scatterplot Smoothing) applied with a 31-year window (Cleveland and Devlin, 1988). More details of the method can be found in Maliniemi et al. (2014).

\section{Results}

\subsection{Global $\mathrm{NO}_{x}, \mathrm{ClO}$ and $\mathrm{O}_{3}$ responses to EPP during 1979-2008}

Figure 3 shows monthly $\mathrm{NO}_{x}$ volume mixing ratio increase in the mesosphere and the stratosphere due to the EPP forcing during 1979-2008. $\mathrm{NO}_{x}$ reaches stratospheric altitudes (below $1 \mathrm{hPa}$ ) in the polar regions during local winter. This is mainly 
due to EEP and to a lesser extent caused by SPEs (Maliniemi et al., 2020), e.g., there were only 3-4 notable SPEs during 1979-2008 as seen in Figure 2b. In the Antarctic stratosphere substantial increase of $\mathrm{NO}_{x}$ is obtained from May until February, reaching roughly $20-30 \mathrm{hPa}$ by late winter/spring. In the Arctic stratosphere the lowest altitude is slightly higher, around 10 hPa during March.
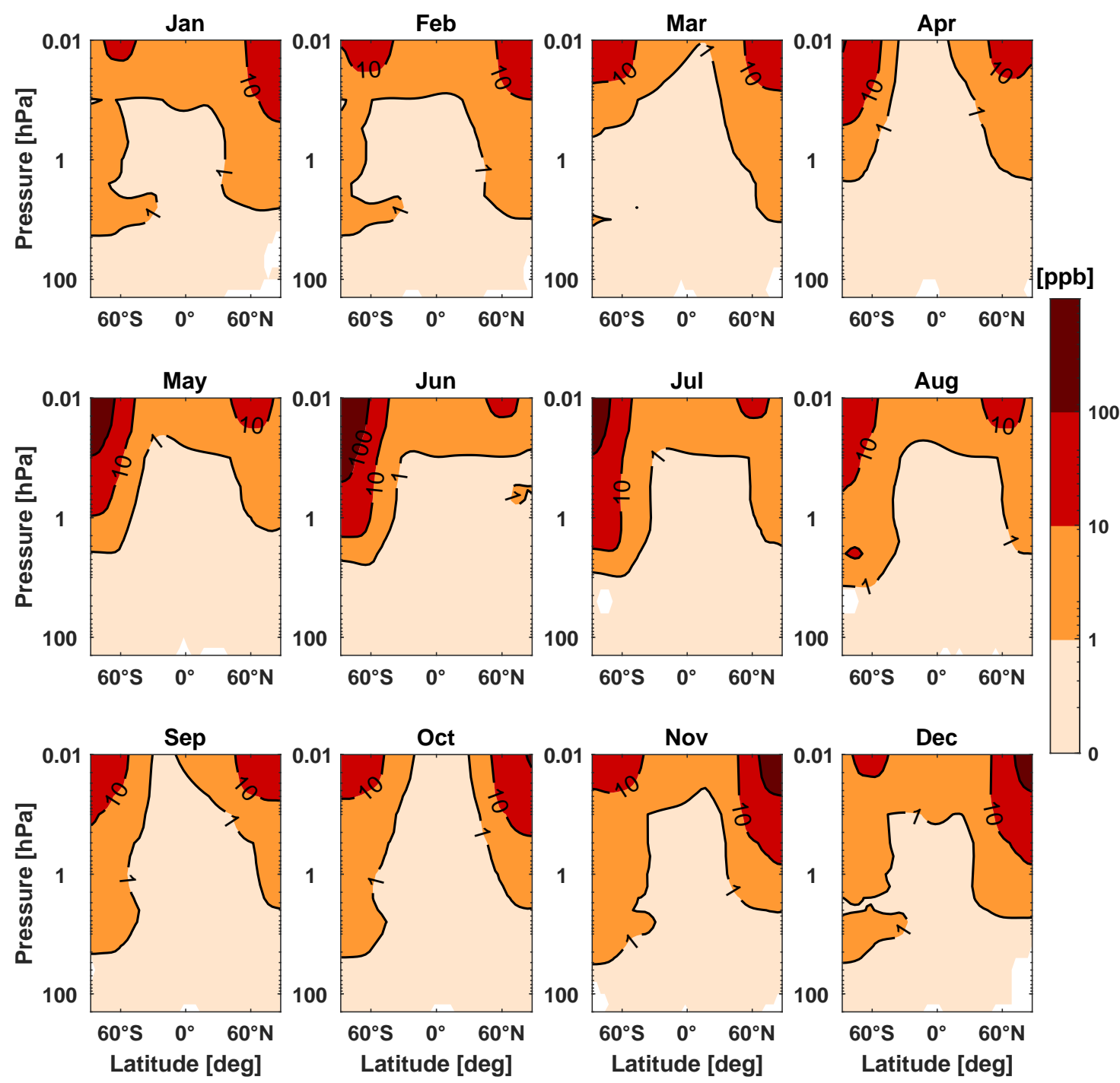

Figure 3. Absolute difference in the monthly zonal mean $\mathrm{NO}_{x}$ between EXP and REF during 1979-2008. Positive contour levels are 1, 10 and 100 parts-per-billion (ppb). Altitude range is from $0.01 \mathrm{hPa}$ to $200 \mathrm{hPa}$. Colour shading indicates areas significant at the $95 \%$ level calculated with a monte carlo simulation and a false detection rate.

EPP leads to ozone depletion in the polar regions in the mesosphere and upper stratosphere as shown in Figure 4. Mesospheric ozone depletion is dominated by $\mathrm{HO}_{x}$ production (Jackman et al., 2008; Andersson et al., 2014; Zawedde et al., 2019), 

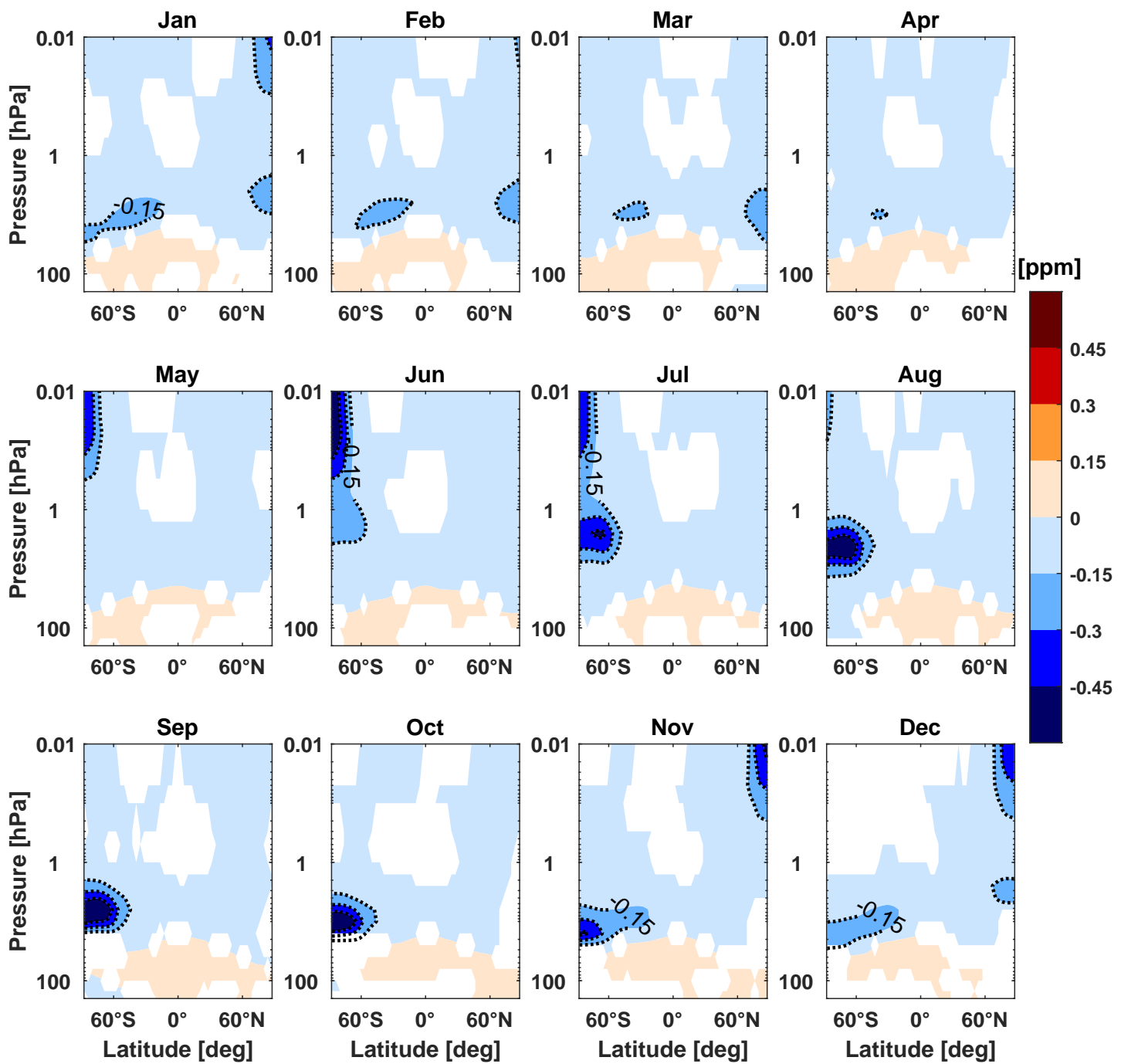

Figure 4. Absolute difference in the monthly zonal mean $\mathrm{O}_{3}$ between EXP and REF during 1979-2008. Negative contour levels are -0.15, -0.3 and -0.45 parts-per-million (ppm). Colour shading indicates areas significant at the $95 \%$ level calculated with a monte carlo simulation and a false detection rate.

the stratospheric ozone depletion is due to $\mathrm{NO}_{x}$ catalytic reactions (R6-R7) (Lary, 1997). It is larger in magnitude and lasts notably longer in the southern hemisphere than in the northern hemisphere, because the strong and stable polar vortex in the southern hemisphere isolates air mass efficiently. Seasonal evolution of the EPP ozone impact is in good agreement with earlier studies (Rozanov et al., 2012; Damiani et al., 2016). There is also a weak but significant Antarctic ozone response at $100 \mathrm{hPa}$ altitude, which is positive from January to May and negative during August-October. This lower stratosphere response is also 
in agreement with Rozanov et al. (2012) and Damiani et al. (2016). Consistently positive weak ozone response in the lower stratosphere outside the polar regions is a consequence of GCR (Calisto et al., 2011; Jackman et al., 2016).
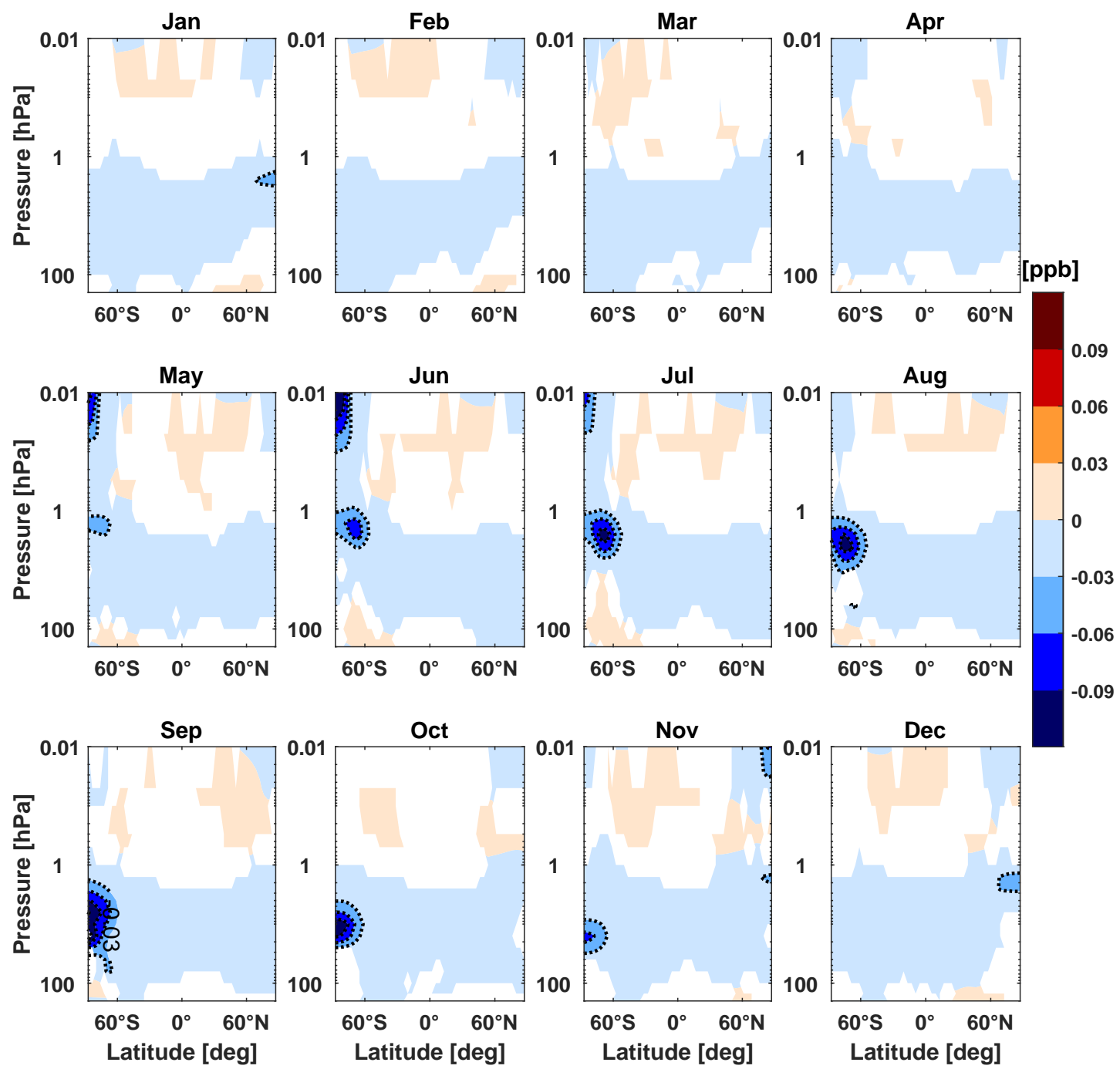

Figure 5. Absolute difference in the monthly zonal mean $\mathrm{ClO}$ between EXP and REF during 1979-2008. Negative contour levels are -0.03, -0.06 and $-0.09 \mathrm{ppb}$. Colour shading indicates areas significant at the $95 \%$ level calculated with a monte carlo simulation and a false detection rate.

Figure 5 shows monthly $\mathrm{ClO}$ volume mixing ratio related to the EPP forcing. Altitude of polar $\mathrm{ClO}$ decrease in the southern hemisphere agrees well with the lowest altitude of $\mathrm{NO}_{x}$ increase during May-November. There is a substantial decrease of $\mathrm{ClO}$ below $1 \mathrm{hPa}$ from June to November in the Antarctic stratosphere, which extends down to $30 \mathrm{hPa}$ in springtime matching the pattern of descending $\mathrm{NO}_{x}$. As explained above, $\mathrm{NO}_{x}$ and $\mathrm{ClO}$ can interact with reactions $\mathrm{R} 8$ and $\mathrm{R} 9$, interfering with the 
catalytic ozone destroying cycles of both agents. Interestingly, there are weak but significantly positive $\mathrm{ClO}$ responses in the Antarctic at $100 \mathrm{hPa}$ altitude during winter (June to September).

\subsection{Antarctic $\mathrm{NO}_{x}, \mathrm{ClO}$ and $\mathrm{O}_{3}$ responses to EPP over the 20th century}

Figure 6 shows the Antarctic polar climatologies of $\mathrm{NO}_{x}, \mathrm{ClO}, \mathrm{ClONO}_{2}$ and $\mathrm{HCl}$ during 1979-2008 from the REF simulation. Small values are denoted in all variables below $200 \mathrm{hPa}$ (not shown). Furthermore, $\mathrm{ClO}$ and $\mathrm{ClONO}_{2}$ have small values above the stratopause (roughly $1 \mathrm{hPa}$ ).
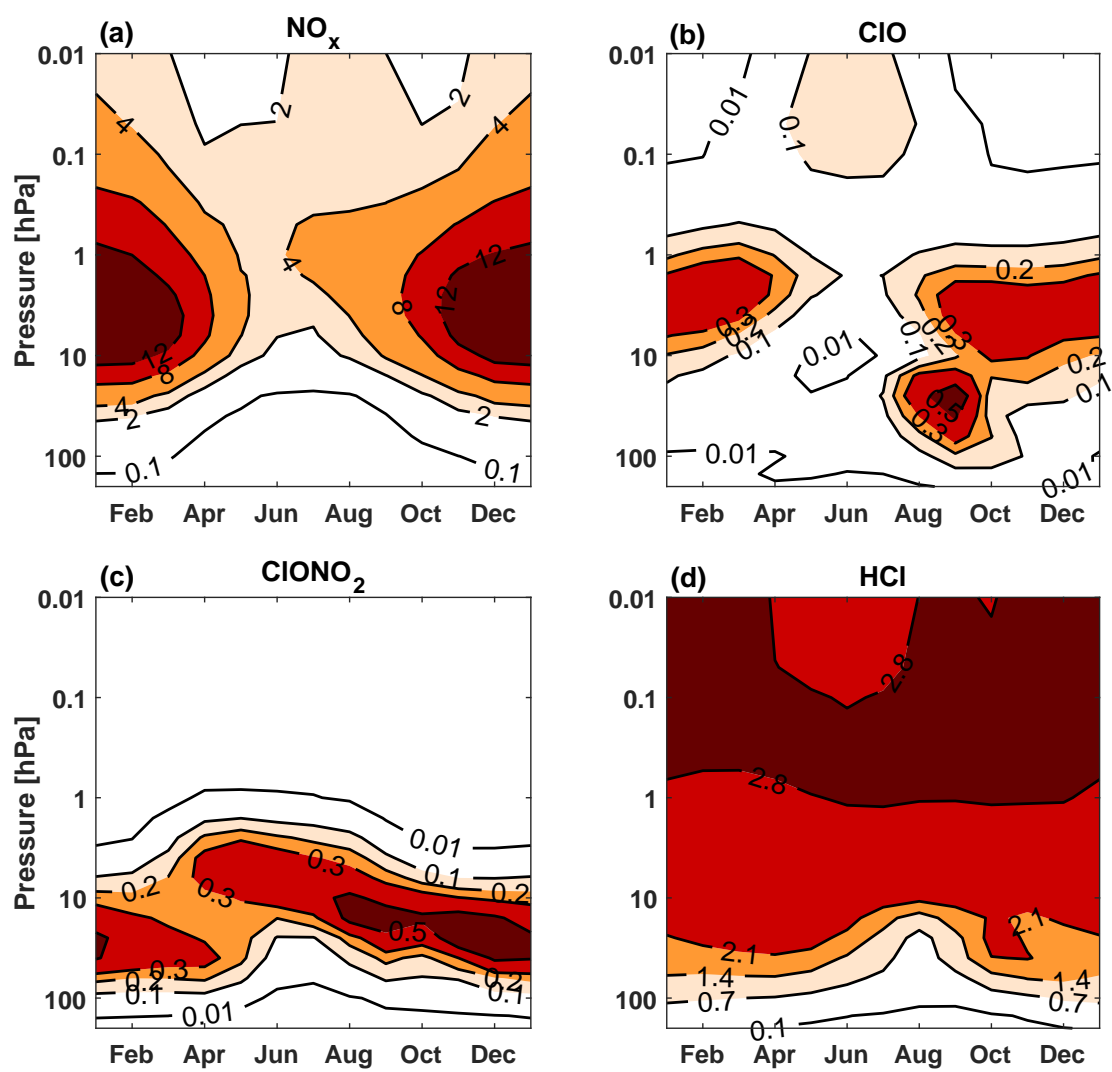

Figure 6. a) Seasonal climatology of $\mathrm{NO}_{x}$ in the Antarctic $\left(70^{\circ} \mathrm{S}-90^{\circ} \mathrm{S}, 0.01-200 \mathrm{hPa}\right)$ during 1979-2008. Positive contour levels are 0.1 , 2 , 4, 8 and $12 \mathrm{ppb}$. Seasonal climatology for b) $\mathrm{ClO}$ and c) $\mathrm{ClONO}_{2}$ are shown with positive contour levels of $0.01,0.1,0.2,0.3$ and $0.5 \mathrm{ppb}$, and for $\mathbf{d}) \mathrm{HCl}$ with positive contour levels of $0.1,0.7,1.4,2.1$ and $2.8 \mathrm{ppb}$. All figures are calculated using the REF simulation, i.e., without the EPP forcing.

Seasonally varying $\mathrm{NO}_{x}$ increase in the Antarctic stratosphere due to EPP is shown in Figure 7a. In addition, SeptemberOctober $\mathrm{NO}_{x}$ abundance at 10-20 hPa in EXP and REF are compared over the whole 20th century in Figures $7 \mathrm{~b}$ and $7 \mathrm{c} . \mathrm{NO}_{x}$ increase of over hundred percent is present in the upper stratosphere during winter. $\mathrm{NO}_{x}$ descends below $10 \mathrm{hPa}$ by July, 
and more than 50 percent increase is sustained until November when the polar vortex typically breaks down. There is also a relative increase of $\mathrm{NO}_{x}$ around 50-100 hPa during June-September. This is directly related to GCR and partly to EEP/SPE from previous season (more than 15 percent increase continues descending after November). Similar increase at these altitudes during mid-winter is also obtained in Rozanov et al. (2012).

The 10-20 $\mathrm{hPa} \mathrm{NO}_{x}$ timeseries for September-October shows that there is a consistent negative trend over the whole 20th century in REF, possibly a consequence of increasing chemical destruction of $\mathrm{NO}_{x}$ in the cooler stratosphere (Stolarski et al., 2015). The $\mathrm{NO}_{x}$ timeseries in EXP is mostly affected by the EEP/geomagnetic activity as can be seen in Figure 2a. However, there is also a negative trend in the EXP NO$x$ timeseries after 1960 in Figure 7b. The EXP NO$x$ level at the end of the simulation is lower than in the beginning despite higher geomagnetic activity in the early 21 st century compared to the early 20 th century.
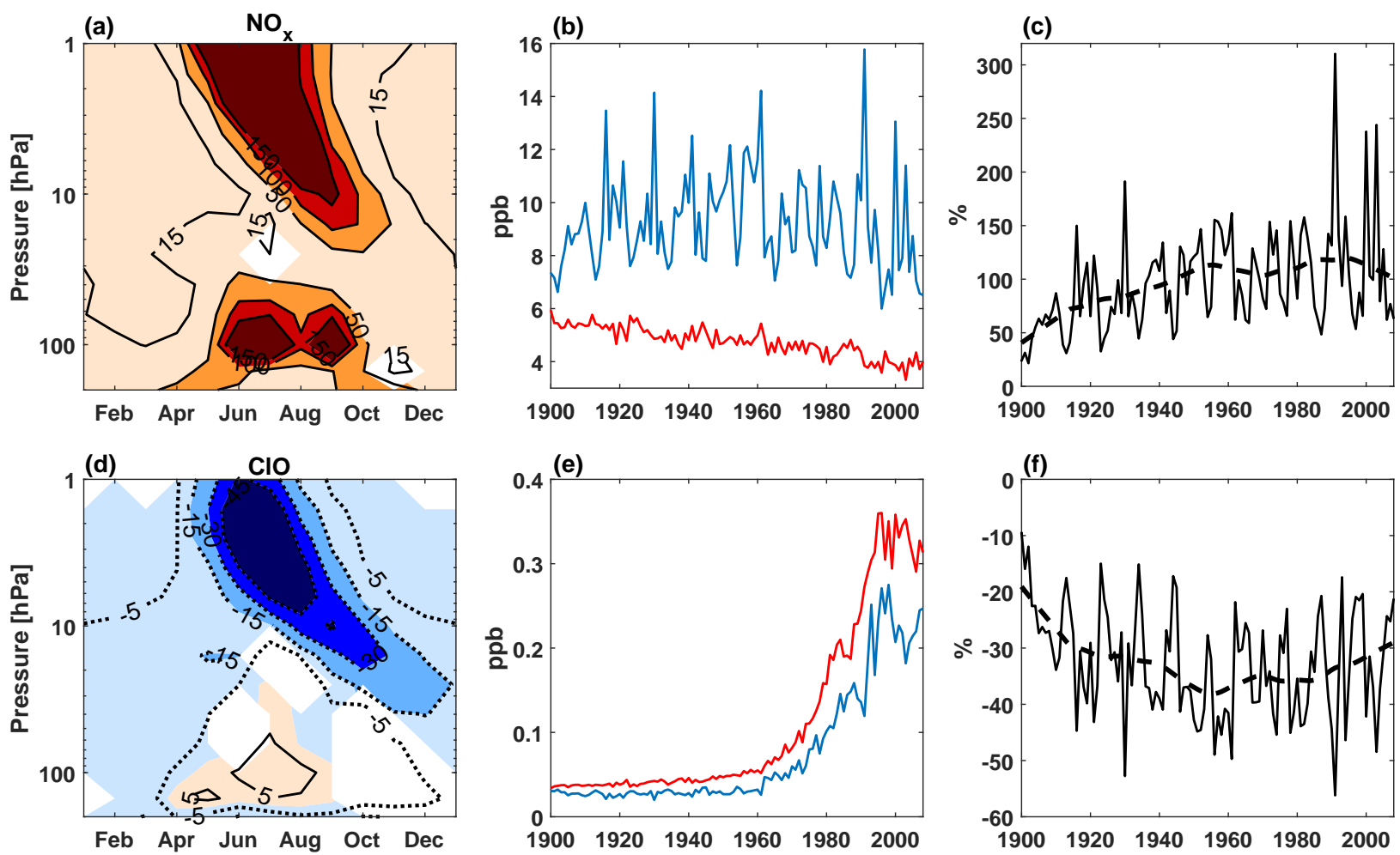

Figure 7. a) Relative difference (EXP-REF/REF) in the monthly zonal mean polar $\mathrm{NO}_{x}\left(70^{\circ} \mathrm{S}-90^{\circ} \mathrm{S}, 1-200 \mathrm{hPa}\right)$ during $1979-2008$. Positive contour levels are 15, 50, 100 and 150 percent (\%). Colour shading indicates areas significant at the $95 \%$ level calculated with a monte carlo simulation and a false detection rate. b) September-October ensemble mean time series of polar $\mathrm{NO}_{x}\left(70^{\circ} \mathrm{S}-90^{\circ} \mathrm{S}, 10-20 \mathrm{hPa}\right)$ in EXP (blue) and REF (red). c) Relative difference of EXP and REF (solid line) and 31-year smooth trend (dotted line). d) Polar ClO with negative contour levels of $-5,-15,-30,-45$ percent (dotted lines) and positive contour level of 5 percent (solid line). e) and f) Same for $\mathrm{ClO}$ as $\mathbf{b}$ ) and c), respectively. 
Figure $7 \mathrm{~d}$ shows relative changes in Antarctic stratospheric $\mathrm{ClO}$ due to the EPP forcing. More than 45 percent decrease in $\mathrm{ClO}$ is obtained between EXP and REF in mid-winter between 1 and $10 \mathrm{hPa}$ in Figure 7d. Loss of more than 15 percent continues well into spring extending down to $40 \mathrm{hPa}$.

The mid-stratospheric $\mathrm{ClO}$ timeseries in September-October (Figures $7 \mathrm{~b}$ and $7 \mathrm{c}$ ) shows that there is a strong increase in chlorine since 1960, due to CFC emissions. However, the ClO amount in EXP consistently falls below the amount in REF. The relative difference between EXP and REF seems to be anticorrelated with the overall level of geomagnetic activity rather than being dependent on the overall amount of $\mathrm{ClO}$. $\mathrm{ClO}$ is reduced by 30-40\% with the EPP forcing at 10-20 hPa in SeptemberOctober after the 1950s.

Interestingly, significant positive $\mathrm{ClO}$ response at $50-100 \mathrm{hPa}$ is present during winter months in Figure $7 \mathrm{~d}$. This occurs at altitudes where polar stratospheric clouds (PSC) form in the Antarctic (Pitts et al., 2018), likely being a consequence of reservoir gases breaking on PSC (Webster et al., 1993). This positive ClO response in the lower stratosphere was also seen in satellite data by Gordon et al. (2021) during August-October.

Figure 8 shows the relative changes in Antarctic stratospheric $\mathrm{ClONO}_{2}$ and $\mathrm{HCl}$ due to the $\mathrm{EPP}$ forcing. Substantial increase of $\mathrm{ClONO}_{2}$ is seen in the upper stratosphere during winter. However, if compared to the climatology of $\mathrm{ClONO}_{2}$ in Figure 6 , it is evident that at altitudes above $3 \mathrm{hPa}$ there is very little $\mathrm{ClONO}_{2}$ and most is located between $3 \mathrm{hPa}$ and $80 \mathrm{hPa}$. Between 3 and $10 \mathrm{hPa}$, negative $\mathrm{ClONO}_{2}$ amount due to EPP is seen during mid-winter. This implies that reduced $\mathrm{ClO}$ due to EPP at this location in Figure $7 \mathrm{~d}$ cannot be explained by reaction R8, but is potentially due to reaction R9 and consequent formation of $\mathrm{HCl}$ seen in Figure 8d (Cl reacting with methane) (Brasseur and Solomon, 2005). In spring time there is a significant $\mathrm{ClONO}_{2}$ increase due to EPP at 10-20 hPa altitudes (Figure 8a), which is also seen in timeseries figures $8 \mathrm{~b}$ and $8 \mathrm{c}$. The relative effect of EPP on $\mathrm{ClONO}_{2}$ increases after 1960, reaching $5 \%$ after 2000.

There is also a significant and strong increase of $\mathrm{ClONO}_{2}$ in the lower stratosphere during winter in Figure 8a accompanied with a significant decrease of $\mathrm{HCl}$ in Figure 8d. It implies that EPP is able to interact with the mechanism of ClO release from $\mathrm{ClONO}_{2}$ and $\mathrm{HCl}$ on PSC (Webster et al., 1993). $\mathrm{ClO}$ is mostly released by consuming $\mathrm{HCl}$ which recovers slowly to initial values, while $\mathrm{ClONO}_{2}$ levels can build up fairly quickly and to excess levels of its initial values (Webster et al., 1993).

The relative effect of EPP on Antarctic ozone shows 10-15 percent decrease in the upper and mid-stratosphere from midwinter until November (Figure 9a). Timeseries of mid-stratospheric (10-20 hPa) ozone in both EXP and REF during SeptemberOctober (Figure 9b) show a negative trend since 1960, but it is notably weaker in EXP. The relative difference between EXP and REF (Figure 9c) shows that the trend correlates negatively with the overall geomagnetic activity before the CFC era. After 1960 the effect of EPP on ozone at 10-20 hPa diverges away from the overall geomagnetic activity level. At the beginning of the 21st century, average ozone depletion due to EPP at 10-20 hPa is just a few percents, and is notably less than in the early 20th century (10 to 15\%) while geomagnetic activity in the early 21 st century is roughly at the level of 1920s/1930s level (Figure 2).

Figure 9a also shows a significant ozone depletion by EPP around $100 \mathrm{hPa}$ altitude during August-October. This is in agreement with $\mathrm{ClO}$ increase seen in Figure $7 \mathrm{~d}$ at same altitude earlier in winter. When polar night ends, $\mathrm{ClO}$ released by PSCs is depleting ozone via ClO-ClO (R3-R5) catalytic cycle (Lary, 1997). 

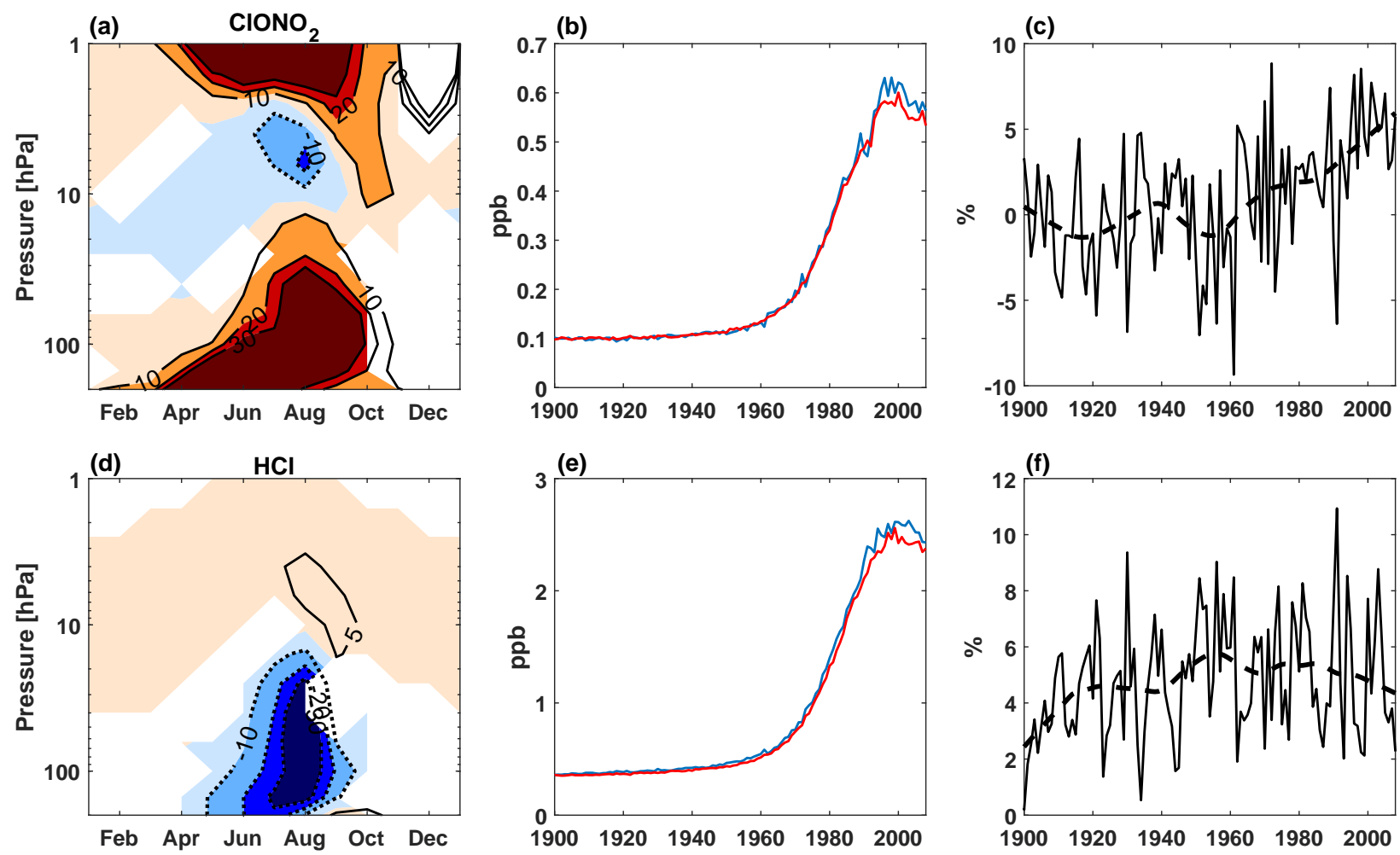

Figure 8. a) Relative difference (EXP-REF/REF) in the monthly zonal mean polar $\mathrm{ClONO}_{2}\left(70^{\circ} \mathrm{S}-90^{\circ} \mathrm{S}, 1-200 \mathrm{hPa}\right) \mathrm{during} 1979-2008$. Positive contour levels (solid lines) are 10, 20 and 30 percent (\%) and negative contour level (dotted line) is -10 percent. Colour shading indicates areas significant at the $95 \%$ level calculated with a monte carlo simulation and a false detection rate. b) September-October ensemble mean time series of polar $\mathrm{ClONO}_{2}\left(70^{\circ} \mathrm{S}-90^{\circ} \mathrm{S}, 10-20 \mathrm{hPa}\right)$ in EXP (blue) and REF (red). c) Relative difference of EXP and REF (solid line) and 31-year smooth trend (dotted line). d) Polar $\mathrm{HCl}$ with negative contour levels of $-10,-20$ and -30 percent (dotted lines) and positive contour level of 5 percent (solid line). e) and f) Same for $\mathrm{HCl}$ as b) and $\mathbf{c}$ ), respectively.

The relative effect of EPP on Antarctic total column ozone (TCO) during 1979-2008 is shown in Figure 9d. It shows 4 to 5 percent decrease in spring (Aug-Oct). When considering the effect on TCO over the whole century in September-October (Figure 9f), it has an average of around 1-3\% reduction until 1980s after which it becomes notably stronger. To understand this evolution in TCO, Figure 10 shows 1900-2008 timeseries of August-October ozone at $100 \mathrm{hPa}$. Relative ozone effect at 100 hPa by EPP is mostly positive (Calisto et al., 2011) until 1980 after which it decreases to minus 5-10 percent level in Figure 10d. This is very different evolution than in the mid-stratosphere in Figure 9c. On the other hand, the EPP effect on TCO after 2000 returns to similar levels than before 1980, which is likely due to reduction in mid-stratospheric ozone depletion as seen in Figure 9c (note roughly an order of magnitude difference in ozone abundance between 10-20 hPa and $100 \mathrm{hPa}$ in Figures 9b and 10c). 

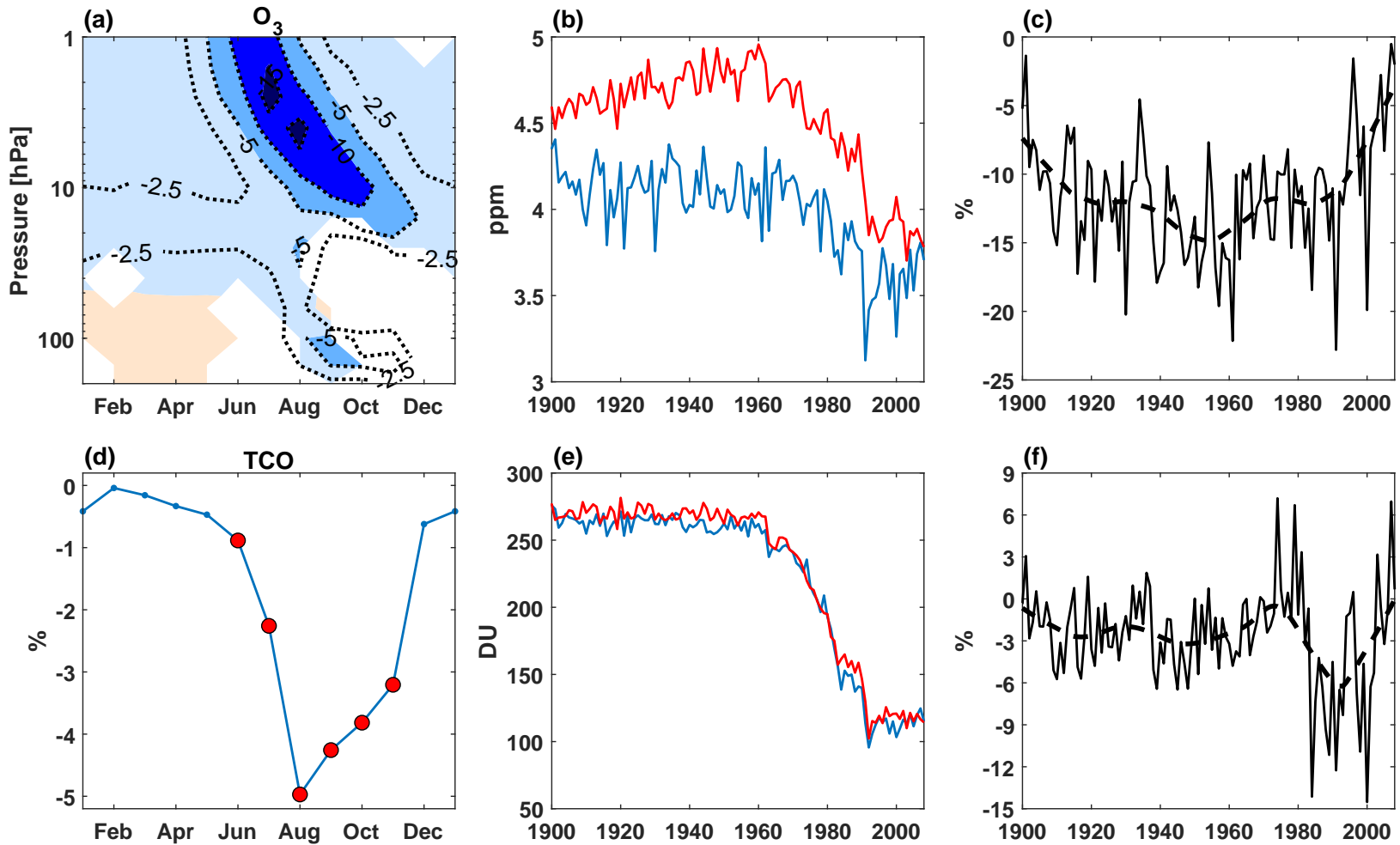

Figure 9. a) Relative difference (EXP-REF/REF) in the monthly zonal mean polar ozone $\left(70^{\circ} \mathrm{S}-90^{\circ} \mathrm{S}, 1-200 \mathrm{hPa}\right)$ during $1979-2008$. Negative contour levels (dotted lines) are $-2.5,-5,-10$ and -15 percent (\%). Colour shading indicates areas significant at the $95 \%$ level calculated with a monte carlo simulation and a false detection rate. b) September-October ensemble mean time series of polar ozone $\left(70^{\circ} \mathrm{S}-90^{\circ} \mathrm{S}, 10-\right.$ 20hPa) in EXP (blue) and REF (red). c) Relative difference of EXP and REF (solid line) and 31-year smooth trend (dotted line). d) Relative effect of EPP on polar total column ozone (TCO). Red circles represent months with significant difference at the $95 \%$ level calculated with a monte carlo simulation and a false detection rate. e) and f) Same for TCO as b) and c), respectively.

The absolute $\mathrm{ClO}$ timeseries at $100 \mathrm{hPa}$ seen in Figure 10a increases substantially after 1960. Interestingly, the relative difference between EXP and REF (Figure 10b) follows the overall level of $\mathrm{ClO}$ (and CFC emissions), and is a very different than in the mid-stratosphere in Figure 7f. Positive $\mathrm{ClO}$ response in the lower stratosphere due to EPP was also found by Gordon et al. (2021). Damiani et al. (2016) showed negative ozone response at same altitudes related to EPP, albeit they were related to regression analysis with the geomagnetic activity. We note that it can be difficult to point to exact source (direct effect by GCR or indirect effect from above by EEP/SPE) in regression studies due to somewhat high collinearity between geomagnetic activity and GCR on interannual scales (Maliniemi et al., 2019). Jackman et al. (2009) showed that nitrogen species $\left(\mathrm{NO}_{y}\right)$ and $\mathrm{ClONO}_{2}$ produced by SPE survive long enough to descend to $100 \mathrm{hPa}$ altitude several months after initial event. These results support that $\mathrm{ClO}$ seen in the lower stratosphere is likely a combination of both EEP/SPE and GCR. We also note that this lower stratospheric $\mathrm{ClO} /$ ozone signal is likely not related to dynamics, i.e., any indirect effects of EPP on the polar vortex and 
(a)

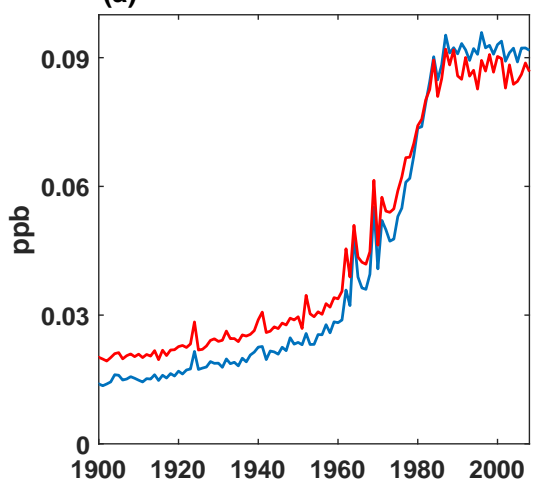

(c)

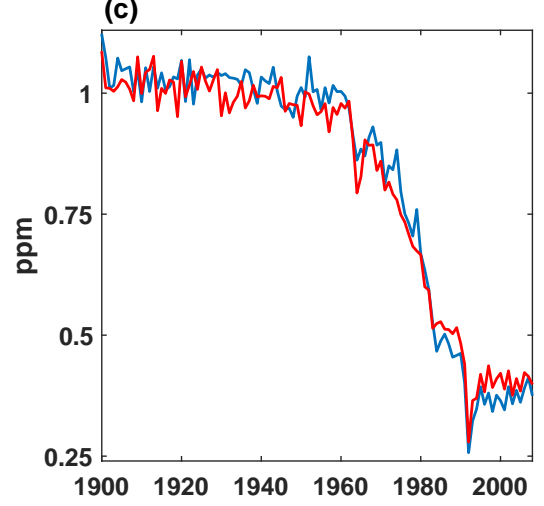

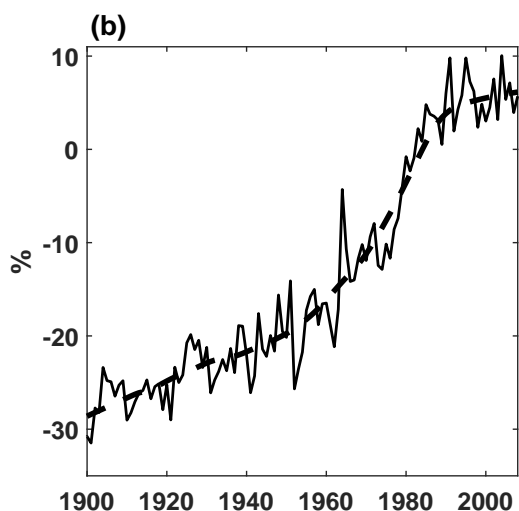

(d)

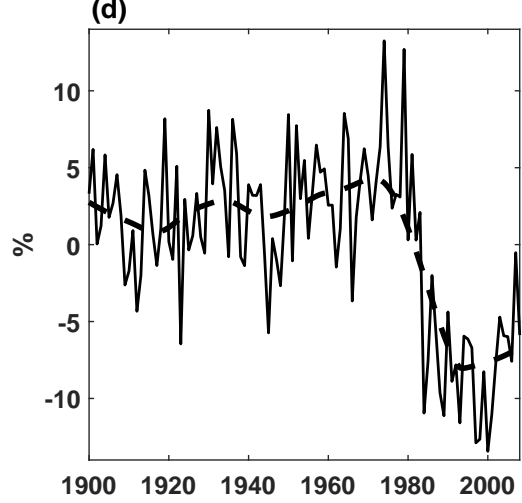

Figure 10. a) Jul-Sep ensemble mean time series of polar $\mathrm{ClO}\left(70^{\circ} \mathrm{S}-90^{\circ} \mathrm{S}, 100 \mathrm{hPa}\right)$ in EXP (blue) and REF (red), with b) relative difference of EXP and REF (solid line) and 31-year smooth trend (dotted line). c) Aug-Oct ensemble mean time series of polar $\mathrm{O}_{3}\left(70^{\circ} \mathrm{S}-90^{\circ} \mathrm{S}, 100 \mathrm{hPa}\right)$ in EXP (blue) and REF (red), with d) relative difference of EXP and REF (solid line) and 31-year smooth trend (dotted line).

meridional circulation. Any notable or significant zonal wind responses (EXP-REF) during winter 1979-2008 was not found (not shown).

\section{Summary}

This study verifies the significant polar stratospheric ozone depletion by EPP during winter over the whole 20th century. The ozone depletion in the upper and mid-stratosphere is a consequence of mostly EEP/geomagnetic activity and partly SPE producing $\mathrm{NO}_{x}$ in the thermosphere and the mesosphere, which then descends to stratospheric altitudes during winter (Seppälä et al., 2007; Funke et al., 2014). In the Antarctic during 1979-2008, ozone depletion varies from more than $10 \%$ in the winter upper stratosphere to 5-10\% in the spring mid- and lower stratosphere between EXP and REF simulations. This is largely in agreement with previous studies (Rozanov et al., 2012; Damiani et al., 2016). The effect of EPP on Antarctic total column ozone is 3-5\% reduction during August to October. 
However, the Antarctic ozone depletion is modulated during the latter half of the 20th century, especially during springtime. The ozone depletion efficiency in the mid-stratosphere weakens towards the beginning of the 21 st century. This weakening of the depletion efficiency (both in absolute and relative terms) is more than expected if only the magnitude of the centennial geomagnetic activity is taken into account. Furthermore, significant ozone depletion by EPP emerges during August-October in the lower Antarctic stratosphere after 1980.

We find a significant decrease of stratospheric $\mathrm{ClO}$ in the same altitude where $\mathrm{NO}_{x}$ is descending seasonally. The relative $\mathrm{ClO}$ reduction in the Antarctic upper and mid-stratosphere varies mainly with the level of geomagnetic activity over the whole century. $\mathrm{EPP}$ can reduce $\mathrm{ClO}$ by $30 \%$ in the upper stratosphere during winter and in the mid-stratosphere during late winter/spring, even during the $\mathrm{CFC}$ era.

In the lower Antarctic stratosphere, $\mathrm{ClO}$ abundance increases by more than 5 percent during winter after 1980. The seasonal emergence of this increase is consistent with the formation of PSCs in the Antarctic, and occurs slightly before the depletion of ozone at the same altitude. We propose that this $\mathrm{ClO}$ increase can be explained by activation of chlorine from reservoir species $\mathrm{ClONO}_{2}$ and $\mathrm{HCl}$.

These results imply that the introduction of CFC emissions since 1960s has significantly influenced the ozone response by EPP. With the implementation of the Montreal Protocol (Velders et al., 2007), ClO amount in the stratosphere is expected to return to pre-CFC levels sometime after the 2050s. Based on results presented here, we can therefore expect higher efficiency of chemical ozone destruction by EPP in the upper stratosphere in the future. Furthermore, recent results have shown that EPP related $\mathrm{NO}_{x}$ is increasing substantially in the future Antarctic upper stratosphere due to stronger vertical transport under climate change (Maliniemi et al., 2020, 2021). This is happening despite the increasing chemical destruction of $\mathrm{NO}_{x}$ in the cooler stratosphere (Stolarski et al., 2015). In summary, 1. higher efficiency of chemical ozone destruction due to the declining CFC levels and 2. stronger vertical transport will make EPP-NO ${ }_{x}$ crucially important for Antarctic upper stratospheric ozone over the coming decades. However, evolution of ozone depletion in the Antarctic lower stratosphere by EPP is more uncertain. More research, e.g., with ideal simulations targeting impacts in future atmospheric state, is needed to quantify the evolution of EPP related ozone response at these altitudes. 
https://doi.org/10.5194/acp-2022-151

Preprint. Discussion started: 2 March 2022

(C) Author(s) 2022. CC BY 4.0 License.

(c) (i)

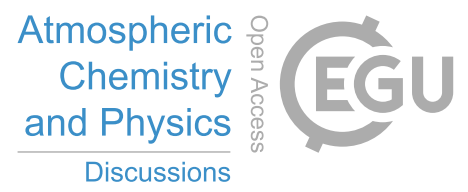

Data availability. SOCOL-MPIOM3 simulations used in this study can be obtained upon a reasonable request (ville.maliniemi@uib.no).

235 Author contributions. V.M and A.S generated the research idea. P.A produced the SOCOL model outputs. V.M analysed the data and wrote the manuscript. All authors contributed to the analyses of the results and modification of the manuscript.

Competing interests. The authors declare no competing interest.

Acknowledgements. The research has been funded by the Norwegian Research Council under Contracts 223252/F50 (BCSS) and 300724 (EPIC). The simulations were performed on resources provided by UNINETT Sigma2 - the National Infrastructure for High Performance 240 Computing and Data Storage in Norway. 


\section{References}

Anderson, J. G., Toohey, D. W., and Brune, W. H.: Free radicals within the Antarctic vortex: the role of CFCs in Antarctic ozone loss, Science, 251, 39-46, https://doi.org/10.1126/science.251.4989.39, 1991.

Andersson, M. E., Verronen, P. T., Rodger, C. J., Clilverd, M. A., and Seppälä, A.: Missing driver in the Sun-Earth connection from energetic electron precipitation impacts mesospheric ozone, Nat. Commun., 5, 5197, https://doi.org/10.1038/ncomms6197, 2014.

Arsenovic, P., Damiani, A., Rozanov, E., Funke, B., Stenke, A., and Peter, T.: Reactive nitrogen $\left(\mathrm{NO}_{y}\right)$ and ozone responses to energetic electron precipitation during Southern Hemisphere winter, Atmos. Chem. Phys., 19, 9485-9494, https://doi.org/10.5194/acp-19-9485$2019,2019$.

Brasseur, G. and Solomon, S.: Aeronomy of the Middle Atmosphere: Chemistry and Physics of the Stratosphere and Mesosphere, https://doi.org/10.1007/1-4020-3824-0, 2005.

Calisto, M., Usoskin, I., Rozanov, E., and Peter, T.: Influence of Galactic Cosmic Rays on atmospheric composition and dynamics, Atmos. Chem. Phys., 11, 4547-4556, https://doi.org/10.5194/acp-11-4547-2011, 2011.

Cleveland, W. S. and Devlin, S. J.: Locally-weighted regression: An approach to regression analysis by local fitting, J. Am. Stat. Assoc., 83, 596-610, https://doi.org/10.2307/2289282, 1988.

Damiani, A., Funke, B., López Puertas, M., Santee, M. L., Cordero, R. R., and Watanabe, S.: Energetic particle precipitation: a major driver of the ozone budget in the Antarctic upper stratosphere, Geophys. Res. Lett., 43, 3554-3562, https://doi.org/10.1002/2016GL068279, 2016.

Egorova, T., Rozanov, E., Zubov, V., and Karol, I.: Model for investigating ozone trends (MEZON), Izv. Atmos. Ocean. Phys., 39, 277-292, 2003.

Funke, B., López-Puertas, M., Stiller, G. P., and Clarmann, T.: Mesospheric and stratospheric $\mathrm{NO}_{y}$ produced by energetic particle precipitation during 2002-2012, J. Geophys. Res., 119, https://doi.org/10.1002/2013JD021404, 2014.

Funke, B., López-Puertas, M., Stiller, G. P., Versick, S., and von Clarmann, T.: A semi-empirical model for mesospheric and stratospheric $\mathrm{NO}_{y}$ produced by energetic particle precipitation, Atmos. Chem. Phys., 16, 8667-8693, https://doi.org/10.5194/acp-16-8667-2016, 2016.

Gordon, E. M., Seppälä, A., Funke, B., Tamminen, J., and Walker, K. A.: Observational evidence of energetic particle precipitation NO$x$ $(\text { EPP-NO })_{x}$ interaction with chlorine curbing Antarctic ozone loss, Atmos. Chem. Phys., 21, 2819-2836, https://doi.org/10.5194/acp-212819-2021, 2021.

Jackman, C. H., Marsh, D. R., Vitt, F. M., Garcia, R. R., Fleming, E. L., Labow, G. J., Randall, C. E., López-Puertas, M., Funke, B., von Clarmann, T., and Stiller, G. P.: Short- and medium-term atmospheric constituent effects of very large solar proton events, Atmos. Chem. Physi., 8, https://doi.org/10.5194/acp-8-765-2008, 2008.

Jackman, C. H., Marsh, D. R., Vitt, F. M., Garcia, R. R., Randall, C. E., Fleming, E. L., and Frith, S. M.: Long-term middle atmospheric influence of very large solar proton events, J. Geophys. Res. Atmos., 114, https://doi.org/10.1029/2008JD011415, 2009.

Jackman, C. H., Marsh, D. R., Kinnison, D. E., Mertens, C. J., and Fleming, E. L.: Atmospheric changes caused by galactic cosmic rays over the period 1960-2010, Atmos. Chem. Phys., 16, 5853-5866, https://doi.org/10.5194/acp-16-5853-2016, 2016.

Lary, D. J.: Catalytic destruction of stratospheric ozone, J. Geophys. Res. Atmos., 102, 21 515-21 526, https://doi.org/10.1029/97JD00912, 1997.

Maliniemi, V., Asikainen, T., and Mursula, K.: Spatial distribution of Northern Hemisphere winter temperatures during different phases of the solar cycle, J. Geophys. Res. Atmos., 119, 9752-9764, https://doi.org/10.1002/2013JD021343, 2014. 
Maliniemi, V., Asikainen, T., Salminen, A., and Mursula, K.: Assessing North Atlantic winter climate response to geomagnetic activity and solar irradiance variability, Q. J. Roy. Meteo. Soc., 145, 3780-3789, https://doi.org/10.1002/qj.3657, 2019.

Maliniemi, V., Marsh, D. R., Nesse Tyssøy, H., and Smith-Johnsen, C.: Will climate change impact polar NOx produced by energetic particle precipitation?, Geophys. Res. Lett., 47, e2020GL087 041, https://doi.org/10.1029/2020GL087041, 2020.

Maliniemi, V., Nesse Tyssøy, H., Smith-Johnsen, C., Arsenovic, P., and Marsh, D. R.: Effects of enhanced downwelling of NO $x$ on Antarctic upper-stratospheric ozone in the 21st century, Atmos. Chem. Phys., 21, 11 041-11 052, https://doi.org/10.5194/acp-21-11041-2021, 2021.

Mann, H. B.: Non-parametric test against trend, Econometrica, 13, 245-259, https://doi.org/10.2307/1907187, 1945.

Marsland, S., Haak, H., Jungclaus, J., Latif, M., and Röske, F.: The Max-Planck-Institute global ocean/sea ice model with orthogonal curvilinear coordinates, Ocean Model., 5, 91-127, https://doi.org/10.1016/S1463-5003(02)00015-X, 2003.

Matthes, K., Funke, B., Andersson, M. E., Barnard, L., Beer, J., Charbonneau, P., Clilverd, M. A., Dudok de Wit, T., Haberreiter, M., Hendry, A., Jackman, C. H., Kretzschmar, M., Kruschke, T., Kunze, M., Langematz, U., Marsh, D. R., Maycock, A. C., Misios, S., Rodger, C. J., Scaife, A. A., Seppälä, A., Shangguan, M., Sinnhuber, M., Tourpali, K., Usoskin, I., van de Kamp, M., Verronen, P. T., and Versick, S.: Solar forcing for CMIP6 (v3.2), Geosci. Model Dev., 10, 2247-2302, https://doi.org/10.5194/gmd-10-2247-2017, 2017.

Meinshausen, M., Smith, S. J., Calvin, K., Daniel, J. S., Kainuma, M. L. T., Lamarque, J., Matsumoto, K., Montzka, S. A., Raper, S. C. B., Riahi, K., Thomson, A., Velders, G. J. M., and van Vuuren, D. P. P.: The RCP greenhouse gas concentrations and their extensions from 1765 to 2300, Clim. Change, 109, 213-241, https://doi.org/10.1007/s10584-011-0156-z, 2011.

Mironova, I. A., Aplin, K. L., Arnold, F., Bazilevskaya, G. A., Harrison, R. G., Krivolutsky, A. A., Nicoll, K. A., Rozanov, E. V., Turunen, E., and Usoskin, I. G.: Energetic Particle Influence on the Earth's Atmosphere, Spa. Sci. Rev., 194, https://doi.org/10.1007/s11214-0150185-4, 2015.

Molina, M. J., Tso, T.-L., Molina, L. T., and Wang, F. C.-Y.: Antarctic Stratospheric Chemistry of Chlorine Nitrate, Hydrogen Chloride, and Ice: Release of Active Chlorine, Science, 238, 1253-1257, https://doi.org/10.1126/science.238.4831.1253, 1987.

Muthers, S., Anet, J. G., Stenke, A., Raible, C. C., Rozanov, E., Brönnimann, S., Peter, T., Arfeuille, F. X., Shapiro, A. I., Beer, J., Steinhilber, F., Brugnara, Y., and Schmutz, W.: The coupled atmosphere-chemistry-ocean model SOCOL-MPIOM, Geosci. Model Dev., 7, 21572179, https://doi.org/10.5194/gmd-7-2157-2014, 2014.

Nesse Tyssøy, H., Haderlein, A., Sandanger, M. I., and Stadsnes, J.: Intercomparison of the POES/MEPED Loss Cone Electron Fluxes With the CMIP6 Parametrization, J. Geophys. Res. Space., 124, https://doi.org/10.1029/2018JA025745, 2019.

Pitts, M. C., Poole, L. R., and Gonzalez, R.: Polar stratospheric cloud climatology based on CALIPSO spaceborne lidar measurements from 2006 to 2017, Atmos. Chem. Phys., 18, 10 881-10 913, https://doi.org/10.5194/acp-18-10881-2018, 2018.

Roeckner, E.: The atmospheric general circulation model ECHAM5: Model description, Hamburg, 2003.

Rozanov, E., Calisto, M., Egorova, T., Peter, T., and Schmutz, W.: Influence of the precipitating energetic particles on atmospheric chemistry and climate, Surv. Geophys., 33, 483-501, https://doi.org/10.1007/s10712-012-9192-0, 2012.

Semeniuk, K., Fomichev, V. I., McConnell, J. C., Fu, C., Melo, S. M. L., and Usoskin, I. G.: Middle atmosphere response to the solar cycle in irradiance and ionizing particle precipitation, Atmos. Chem. Phys., 11, 5045-5077, https://doi.org/10.5194/acp-11-5045-2011, 2011.

Seppälä, A., Verronen, P. T., Clilverd, M. A., Randall, C. E., Tamminen, J., Sofieva, V., Backman, L., and Kyrölä, E.: Arctic and Antarctic polar winter NOx and energetic particle precipitation in 2002-2006, Geophys. Res. Lett., 34, https://doi.org/10.1029/2007GL029733, 2007. 
https://doi.org/10.5194/acp-2022-151

Shapiro, A. I., Schmutz, W., Rozanov, E., Schoell, M., Haberreiter, M., Shapiro, A. V., and Nyeki, S.: A new approach to the long-term reconstruction of the solar irradiance leads to large historical solar forcing, A\&A, 529, A67, https://doi.org/10.1051/0004-6361/201016173, 2011.

Solomon, S., Crutzen, P. J., and Roble, R. G.: Photochemical coupling between the thermosphere and the lower atmosphere: 1. Odd nitrogen from 50 to 120 km, J. Geophys. Res., 87, https://doi.org/10.1029/JC087iC09p07206, 1982.

Stenke, A., Schraner, M., Rozanov, E., Egorova, T., Luo, B., and Peter, T.: The SOCOL version 3.0 chemistry-climate model: description, evaluation, and implications from an advanced transport algorithm, Geosci. Model Dev., 6, 1407-1427, https://doi.org/10.5194/gmd-61407-2013, 2013.

Stolarski, R. S., Douglass, A. R., Oman, L. D., and Waugh, D. W.: Impact of future nitrous oxide and carbon dioxide emissions on the stratospheric ozone layer, Environ. Res. Lett., 10, https://doi.org/10.1088/1748-9326/10/3/034011, 2015.

Velders, G. J. M., Andersen, S. O., Daniel, J. S., Fahey, D. W., and McFarland, M.: The importance of the Montreal Protocol in protecting climate, Proc. Natl. Acad. Sci., 104, https://doi.org/10.1073/pnas.0610328104, 2007.

Webster, C. R., May, R. D., Toohey, D. W., Avallone, L. M., Anderson, J. G., Newman, P., Lait, L., Schoeberl, M. R., Elkins, J. W., and Chan, K. R.: Chlorine Chemistry on Polar Stratospheric Cloud Particles in the Arctic Winter, Science, 261, 1130-1134, https://doi.org/10.1126/science.261.5125.1130, 1993.

Wilks, D. S.: "The stippling shows statistically significant grid points": how research results are routinely overstated and overinterpreted, and what to do about it, Bull. Am. Meteorol. Soc., 97, https://doi.org/10.1175/BAMS-D-15-00267.1, 2016.

WMO: Scientific assessment of ozone depletion: 2018, Global Ozone Research and Monitoring Project - Report No. 58, 588 pp., Geneva, Switzerland, 2018.

Zawedde, A. E., Nesse Tyssøy, H., Stadsnes, J., and Sandanger, M. I.: Are EEP Events Important for the Tertiary Ozone Maximum?, J. Geophys. Res. Space, 124, 5976-5994, https://doi.org/10.1029/2018JA026201, 2019. 